\title{
The Body (Weight and Composition) of Evidence in COPD
}

\author{
Francesco Spelta* \\ Department of Internal Medicine, University of Verona, Italy
}

Submission: August 29, 2018; Published: September 12, 2018

*Corresponding author: Francesco Spelta, Department of Internal Medicine, University of Verona, Verona, Italy, Tel: 00393283653164; Email: francesco.spelta@univr.it

\section{Opinion}

The importance of body weight in COPD in relation to clinical outcomes has been deeply studied for many years. Large population studies have shown since many years that a low Body Mass Index (i.e. underweight, $\mathrm{BMI}<20$ ) is an independent strong predictor of both all-cause and COPD-related mortality [1].

Noteworthy, it is the trajectory of weight changes during time that has to be carefully considered in these patients, being unintended weight loss an accepted determinant of reduced survival [2] rather than a compensatory mechanism to decrease metabolic rate in the advanced stages of the disease or an unavoidable epiphenomenon of the very end-stage. Indeed, the most severe the disease, the higher the prevalence of underweight patients [1,3]. A similar trend is related to the emphysema extent, where an association with loss of fat and Fat-Free Mass (FFM) has been observed, leading to a decreased BMI [4]. Moreover, Lung Volume Reduction Surgery (LVRS) has been demonstrated to significantly increase BMI and ameliorate health status [5]. Taken together, these evidences suggest a close interaction between body weight and the disease itself: different characteristics of the disease (both clinical severity and pathological and anatomical features) have a strong and significant impact on body weight and composition.

More recently, a careful look has been focused on the other end of the BMI spectrum, with some evidences indicating a protective role of overweight and obesity in comparison of not only underweight, but also normal weight in COPD patients, the so called "obesity paradox"[1]in terms of morbidity and mortality. Several potential mechanisms have been proposed to explain this - probably apparent but surely multifactorial - paradox [6]. Among them we can find - again - disease characteristics, and body composition. In fact, the beneficial effect of increased BMI is stronger in the severe cases. For the latter point, it is not well understood if it is an excess in fat or a preserved FFM that contributes to this survival advantage [2].To address the last question, and to further describe the importance of body composition in COPD, it may be useful to focus on the subgroup of patients who show the characteristics of Sarcopenic Obesity (SO).

Sarcopenia is defined by the simultaneous presence of poor muscle function and a low muscle mass in older people[7], being sarcopenic obesity a condition characterized by excessive body weight, mostly with abdominal obesity, and a disproportional low muscle mass [8]. This metabolic phenotype [2] is highly prevalent in COPD [8]: subjects with SO were three times more frequent among COPD patients in comparison to smokers and non-smokers controls among the participants to the ECLIPSE study [9]. However, no mortality data are available for this subgroup of patients to date and results evaluating functional outcomes are conflicting since a reduction in physical performance (reduction in the distance walked in 6 minutes) has been observed in SO patients in comparison to sarcopenic nonobese [9], but also SO patients showed a higher muscle strength compared to the sarcopenic non-obese in another setting [8].

It is clear that the systemic burden of COPD plays a pivotal role in the natural history of the disease and that the multisystems interaction is complex and far from a full comprehension. Moreover, the natural history itself is a player to take into consideration, since any intervention can have beneficial to detrimental effects, depending on the timing of its action. As an example, related to metabolism, the role of the Insulin IGF-1 - mTOR pathway is significant. A downregulation of this important nutrient signaling pathway, has been shown to be related to an extended lifespan in different species [10], slowing the aging process. COPD is related to several hallmarks of aging (like chronic inflammation, cell senescence, defective autophagy, increased oxidative stress) and mTOR levels are elevated [11]. Of interest, some preclinical studies evaluating the mTOR inhibitor rapamycin showed promising results, in terms of improvement in lung function parameters [11]. However, inhibiting mTOR leads to a decreased protein synthesis and eventually to a possible decreasing muscle growth and possibly sarcopenia [12]. Muscle wasting in COPD is a complex phenomenon, that involves different mechanisms during time [13], being the mTOR 
pathway only a part of it, although important. Future studies are needed in the field.

In 1968 Filley et al.[14]described what is considered the traditional classification of COPD, the definition of "Pink Puffers" and "Blue Bloaters" [14], being body weight an important part of the description. After 50 years, the definition is still relevant while a bigger effort should be put in clinical settings and on a daily basis in order to prevent the onset of the disease and eventually its dramatic evolution.

\section{References}

1. Landbo C, Prescott E, Lange P, Vestbo J, Almdal TP (1999) Prognostic Value of Nutritional Status in Chronic Obstructive Pulmonary Disease. Am J Respir Crit Care Med 160(6): 1856-1861.

2. Schols AM, Ferreira IM, Franssen FM, Gosker HR, Janssens W, et al. (2014) Nutritional assessment and therapy in COPD: a European Respiratory Society statement. Eur Respir J 44(6): 1504-1520.

3. Schols AMWJ, Broekhuizen R, Weling Scheepers CA, Wouters EF (2005) Body composition and mortality in chronic obstructive pulmonary disease. Am J Clin Nutr 82(1): 53-59.

4. Kurosaki H, Ishii T, Motohashi N, Motegi T, Yamada K, et al. (2009) Extent of emphysema on HRCT affects loss of fat-free mass and fat mass in COPD. Intern Med 48(1): 41-48.

5. Oey IF, Bal S, Spyt TJ, Morgan MDL, Waller DA (2004) The increase in body mass index observed after lung volume reduction may act as surrogate marker of improved health status. Respir Med 98(3): 247253.
6. Spelta F, Fratta Pasini AM, Cazzoletti L, Ferrari M (2018) Body weight and mortality in COPD: focus on the obesity paradox. Eat Weight Disord 23(1): 15-22.

7. McKee A, Morley JE, Matsumoto AM, Vinik A (2017) Sarcopenia: an endocrine disorder? Endocrine practice 23(9): 1140-1149.

8. Van de Bool C, Rutten EPA, Franssen FME, Wouters EFM, Schols AMW] (2015) Antagonistic implications of sarcopenia and abdominal obesity on physical performance in COPD. Eur Respir J 46(2): 336-345.

9. Joppa P, Tkacova R, Franssen FME, Hanson C, Rennard SI, et al. (2016) Sarcopenic obesity, functional outcomes, and systemic inflammation in patients with chronic obstructive pulmonary disease. Journal of the American Medical Directors Association 17(8): 712-718.

10. Fontana L, Partridge L, Longo VD (2010) Extending healthy life spanfrom yeast to humans. Science 328(5976): 321-328.

11. Kennedy BK, Pennypacker JK (2016) Mammalian target of rapamycin: a target for (lung) diseases and aging. Annals ATS 13(Supp 5): S398-S401.

12. Morley JE (2016) The mTOR conundrum: essential for muscle function, but dangerous for survival. Journal of the American Medical Directors Association 17(11): 963-966.

13. Langen RCJ, Gosker HR, Remels AHV, Schols AMWJ (2013) Triggers and mechanisms of skeletal muscle wasting in chronic obstructive pulmonary disease. Int J Biochem Cell Biol 45(10): 2245-2256.

14. Filley GF, Beckwitt HJ, Reeves JT, Mitchell RS (1968) Chronic Obstructive Bronchopulmonary Disease. II. Oxygen Transport in Two Clinical Types. Am J Med 44(1): 26-38.

Your next submission with Juniper Publishers will reach you the below assets

- Quality Editorial service

- Swift Peer Review

- Reprints availability

- E-prints Service

- Manuscript Podcast for convenient understanding

- Global attainment for your research

- Manuscript accessibility in different formats

( Pdf, E-pub, Full Text, Audio)

- Unceasing customer service

Track the below URL for one-step submission https://juniperpublishers.com/online-submission.php 